\title{
Populational Fluctuation of Vectors of Xylella fastidiosa, Wells in Sweet Orange [Citrus sinensis (L.) Osbeck] Varieties of Northwest Paraná State, Brazil
}

\author{
Rúbia de Oliveira Molina, Aline Maria Orbolato Gonçalves, Carlos Alexandre Zanutto and \\ William Mário de Carvalho Nunes* \\ Núcleo de Pesquisa em Biotecnologia Aplicada; Universidade Estadual de Maringá; Av. Colombo, 5790; 87020- \\ 900; Maringá - PR - Brasil
}

\begin{abstract}
The aim of the present study was to assess the population flutuation of the sharpshooters species subfamily Cicadellinae belonging to the tribes Cicadellini and Proconiini, in sweet orange [Citrus sinensis( L). Osbeck] commercial orchards of the northwest region of Paraná State, Brazil. Samplings were carried out the employing every time 24 yellow sticky cards. Identification of the species showed that the most representative were Dilobopterus costalimai of the Cicadellini tribe and Acrogonia citrina of the Proconiini tribe.
\end{abstract}

Key words: Sharpshooter, Cicadellidae, Citrus variegated chlorosis

\section{INTRODUCTION}

Citriculture represents an important role in the Brazilian economy. However, the crop is affected by a number of diseases, being the citrus variegated chlorosis (CVC) one of the biggest problems. The causal agent is the bacterium Xylella fastidiosa, found for the first time in Brazil in 1987 in Colina county orchards, São Paulo State, and in the region of the Minas Gerais State. In the Paraná State, the CVC were observed, initially, in the city of Paranavaí, PR. in 1992 (Leite and Jacomino, 1993). About 50\% of citrus orchards were established in the Northwest region of the State of Paraná (Fidalski et al., 2000).

The causal agent of the CVC can infect many species, cultivars and hybrids of Citrus spp, being the sweet oranges (Citrus sinensis) the most susceptibles. Mandarins (Citrus reticulata) are the ones that reveal less severe symptoms. Rangpur lime (Citrus limonia), lemons (Citrus limon), cider (Citrus medica) and pummelos (Citrus grandis) are tolerant to the disease (Rosseti and De Negri, 1990). Habermann et al. (2006), showed the importance of xylem occlusion and diffusive disturbances in diseased plants, in relation to root initiation capacity and hormonal translocation in the plant tissue.

CVC does not kill the susceptible plant, but it causes damages to the culture diminishing the quality of the fruits, turning them unsuitable for the commercialization "in natura", as well as for the concentrated juice production. Purcell (1979) confirmed that $X$. fastidiosa depended on insects vectors, the sharpshooter (Hemiptera, Cicadellidae), for its natural dissemination by introduction in susceptible tissue. Besides CVC, some other diseases, caused by this bacterium,

\footnotetext{
*Author for correspondence: wmcnunes@uem.br
} 
such as Pierces disease in grapevine (Vitis vinifera L.), phony peach in peach [Prunus persicae (L.) Batsch], leaf scorch in plum (Prunus salicina Lindl) and coffee (Coffea arabica L.) (Beretta et al., 1996; Paradella et al., 1995), where sharpshooters have been confirmed as vectors.

The insects transmit the bacteria to healthy plants once they get contaminated by feeding on diseased plants. Normally, they feed sucking the sap of the xylem of leaves and young twigs (Lopes et al., 1996; Roberto et al., 1996). Among the vectors species they found Dilobopterus costalimai Young, Acrogonia citrina Marucci and Carvichioli, Oncometopia facialis (Signoret), Macugonalia leucomelas (Walker), Bucephalogonia xanthophis (Berg), Ferrariana trivittata (Signoret), Sonesimia grossa (Signoret), Homalodisca ignorata (Melichar) and Plesiomata corniculata Young.

The bacterium can be transmitted by sharpshooters in all its phases of development (Purcell, 1979). However, the most important phase for the transmission is the adult, thanks to it's long period of life. In the citrus plants, the adults are more easily observed; however, nymphs and eggs can also be found. Nymphs also transmit $X$. fastidiosa, but, they lose the transmission capacity after ecdise, when the instar change occurs or undergo to the adult phase (Freitag, 1951; Purcell and Finlay, 1979).

Little is known on the relations between the $X$. fastidiosa and its vectors in Brazil. Information exists on the transmission by sharpshooter of other strains of $X$. fastidiosa, that can be directly applied to the study with CVC. It is believed that the mechanism of transmission of the strain of citrus is similar to the one of other strains of Xylella. However, it is believed that variations in some characteristics may occur, such as time needed for acquisition or inoculation by the vector, latent period, efficiency of transmission, persistence of the bacterium in the vector, and incubation period in the plant after inoculation by the vector (Lopes, 1996).

The majority of the species of sharpshooters is not very efficient in the transmission of the $X$. fastidiosa, presenting less than $5 \%$ of transmission (Lopes, 1996). But as they are in very high number in the orchards, the disease spreads with much easiness. Some species of sharpshooters contaminate only two in each 100 trees where they feed. Roberto and Yamamoto (1998), found only few works that study, in the correct identification of species, biology, ecology, transmission and control of sharphooter in the orchard. In studying the population fluctuation of sharphooter these authors observed that the population were influenced by the climate. The years of normal rain distribution, the population tended to be bigger and the colonization occurred at the beginning of the spring. They concluded that knowing the behavior of the population of sharphooters in citrus orchards throughout the time was essential for the adoption of strategies of management and control.

The objective of this work was to evaluate the population fluctuation of sharpshooter vetors of the $X$. fastidiosa in sweet orange [Citrus sinensis (L.) Osbeck] orchards of the varieties Natal, Folha Murcha, Valência and Pêra, located in a commercial orchard in the Northwest region of the State of Paraná, Brazil.

\section{MATERIAL AND METHODS}

Sharpshooter adults belonging to the Cicadellidae family were collected in a commercial orchard of sweet orange, formed by the varieties Natal, Pêra, Valência and Folha Murcha, with approximately 2,000 plants each. The orchard is in a property in of the northwest region of Paraná State, located in Latitude S $23^{\circ} 12^{\prime}$ 47,013', Longitude W 52 ${ }^{\circ} 17^{\prime}$ 59,391".

The sampling of the insects was carried out by means of yellow adhesive traps (Biocontrole $\AA$ ) with dimensions of $9.0 \mathrm{~cm} \times 12.0 \mathrm{~cm}$, placed in the north face of the plants and fixed in the external part of the canopy to a height of $1.70 \mathrm{~m}$ from the ground. The traps were distributed in the periphery and central area of the orchard. A trap was placed between the first and fifth plant with a repetition between the 45 th and 50 th plant in the same row. Three rows of each variety were analyzed, total 06 labels per plots and 24 in the property. The traps were renewed monthly in the orchard. The collections were carried between the years of 2000 and 2002.

After collection in the field, the traps were taken to the laboratory and the samples of the sharpshooters species were removed using kerosene to dissolve the glue and to separate the material. The identification of the species was carried out by means of a stereoscopic microscope and with the aid of a visual key of insect identification (Marucci et al., 1999; 2002). 
For the identification of some species, the study of the internal genitalia of the males was undertaken, using the procedure of removal of the entire abdomen with stilettos; treatment with $10 \%$ sodium hydroxide $(\mathrm{NaOH})$ solution warmed in water bath for $3 \mathrm{~min}$ and afterwards washed in distilled water, during 10 minutes and transferred to a slide for observation on stereoscopic. All the sharpshooter removed were conserved in labeled acrylic bottles in $70 \%$ alcohol and stored at room temperature (Marucci, 1998).

To study the population fluctuation of sharpshooter vectors, the total numbers of insects captured monthly, were used. The obtained numbers were transformed in the $(\sqrt{x+10})$ for the homogenization of variances and normalitys of the errors, being submitted to the variance analysis, considering the entire random delineation. The data was processed using the software SISVAR. The test used for the comparison of the averages of the species number was the Scott-Knott to the level of 0.05 of significance.

\section{RESULTS AND DISCUSSION}

Eleven species of sharphooter were captured in the orchard during these three years, which were Dilobopterus costalimai, Acrogonia citrina, Bucephalogonia xanthophis, Ferrariana trivittata, Homalodisca ignorata, Hortencia similis, Macugonalia cavifrons, Macugonalia leucomelas, Oncometopia facialis, Plesiommata corniculata and Sonesimia grossa. The identified species belonged to the Cicadellidae family, subfamily Cicadellinae, tribes Cicadellini and Proconiini. The species most frequent in the evaluated varieties were $D$. costalimai and A. citrina (Table 1).

Table 1 - Number and frequency of sharpshoopters collected in yellow adhesive traps in the period of 2000 the 2002 in the Nova Esperança town, PR.

\begin{tabular}{lcccccccc}
\hline \multirow{2}{*}{ Cicadellini \& Proconiini } & \multicolumn{2}{c}{ Natal } & \multicolumn{2}{c}{ Pêra } & \multicolumn{2}{c}{ Valência } & \multicolumn{2}{c}{ F. Murcha } \\
\cline { 2 - 9 } & $\mathbf{N}$ & $\mathbf{F \%}$ & $\mathbf{N}$ & $\mathbf{F \%}$ & $\mathbf{N}$ & $\mathbf{F \%}$ & $\mathbf{N}$ & $\mathbf{F \%}$ \\
\hline Dilobopterus costalimai & 120 & $49,8 \%$ & 209 & $80,0 \%$ & 97 & $83,0 \%$ & 169 & $68,0 \%$ \\
Acrogonia citrina & 102 & $42,4 \%$ & 32 & $12,5 \%$ & 7 & $6,0 \%$ & 43 & $18,0 \%$ \\
Bucephalogonia xanthophis & 8 & $3,3 \%$ & 6 & $2,3 \%$ & 3 & $2,5 \%$ & 6 & $2,4 \%$ \\
Ferrariana trivittata & 0 & $0,0 \%$ & 1 & $0,4 \%$ & 2 & $1,7 \%$ & 2 & $0,8 \%$ \\
Homalodisca ignorata & 0 & $0,0 \%$ & 0 & $0,0 \%$ & 2 & $1,7 \%$ & 4 & $1,6 \%$ \\
Hortência similis & 1 & $0,4 \%$ & 0 & $0,0 \%$ & 0 & $0,0 \%$ & 2 & $0,8 \%$ \\
Macugonalia cavifrons & 0 & $0,0 \%$ & 0 & $0,0 \%$ & 1 & $0,8 \%$ & 0 & $0,0 \%$ \\
Macugonalia leuconelas & 3 & $1,2 \%$ & 0 & $0,0 \%$ & 1 & $0,8 \%$ & 0 & $0,0 \%$ \\
Oncometopia facialis & 7 & $2,9 \%$ & 2 & $0,8 \%$ & 2 & $1,7 \%$ & 2 & $0,8 \%$ \\
Plesiommata corniculata & 0 & $0,0 \%$ & 1 & $0,5 \%$ & 0 & $0,0 \%$ & 0 & $0,0 \%$ \\
Sonesimia grossa & 0 & $0,0 \%$ & 9 & $3,5 \%$ & 2 & $1,8 \%$ & 19 & $7,6 \%$ \\
\hline TOTAL & 241 & $100,0 \%$ & 260 & $100,0 \%$ & 117 & $100,0 \%$ & 247 & $100,0 \%$ \\
\hline
\end{tabular}

Note: $\mathrm{N}=$ total number of species captured in the period; $\mathrm{F}(\%)=$ percentage of individuals of determined species in relation to the total of captured individuals.

The species D. costalimai, was the mastered prevalent, found in the varieties Pêra, Folha Murcha and Valência, differing statistically only from the Natal variety where the average was similar to the average of the species A. citrina (Table 2). Paiva et al. (1996), turned that in São Paulo orchards these species occured more in citrus plants than on weeds, and that $D$. costalimai was the most captured species. This is explained by the high temperatures could be in this period and by favorable biological conditions such as abundant ground vegetation, where many search for food for the propagation of the species (Molina et al., 2007; Gonçalves et al., 2008).

The varieties Pêra and Folha Murcha presented the biggest numbers of vectors species captured, an the variety Valência, presented the lesser amount of captured insects, when compared with the other varieties during the three evaluated years (Table 1).

In the Natal variety, other three species of great importance were captured: Bucephalogonia xanthophis, Oncometopia facialis and Macugonalia leucomelas (Table 1). Even being 
captured in lesser amounts these were important since these vectors were efficient in the transmission of $X$. fastidiosa and possessed high index of natural infectivity (Lopes et al., 1999). Yamamoto et al. (2002), observed the predominance of the species $B$. xanthophis in citrus nurseries. The highest incidences of sharpshooter was in 2001, for the four evaluated varieties (Fig. 1).

Table 2 - Number of sharpshoopters [monthly average $(\sqrt{x+10})$ ] captured in citrus orchards of Pêra, Valência, Folha Murcha and Natal varities in the years of 2000, 2001 and 2002.

\begin{tabular}{lcccccccc}
\hline & Pêra & \multicolumn{3}{c}{ Folha Murcha } & Valência & & Natal & \\
\hline Acrogonia citrina & 1,328792 & A & 1,477500 & A & 1,076858 & A & 1,516082 & B \\
Dilobopterus costalimae & 2,01729 & B & 1,793264 & B & 1,537295 & B & 1,695754 & B \\
Others vectors & 1,226106 & A & 1,329210 & A & 1,234641 & A & 1,163854 & A \\
Othres cicadelids & 3,244475 & C & 3,012263 & C & 2,935562 & C & 2,887664 & C \\
\hline TOTAL & 7,816663 & & 7,612237 & & 6,784356 & & 7,263354 & \\
\hline
\end{tabular}

Note: Averages followed by the same capital letter in the column belong to the same criterion of grouping by the Scott-Knott test at $5 \%$ of probability.

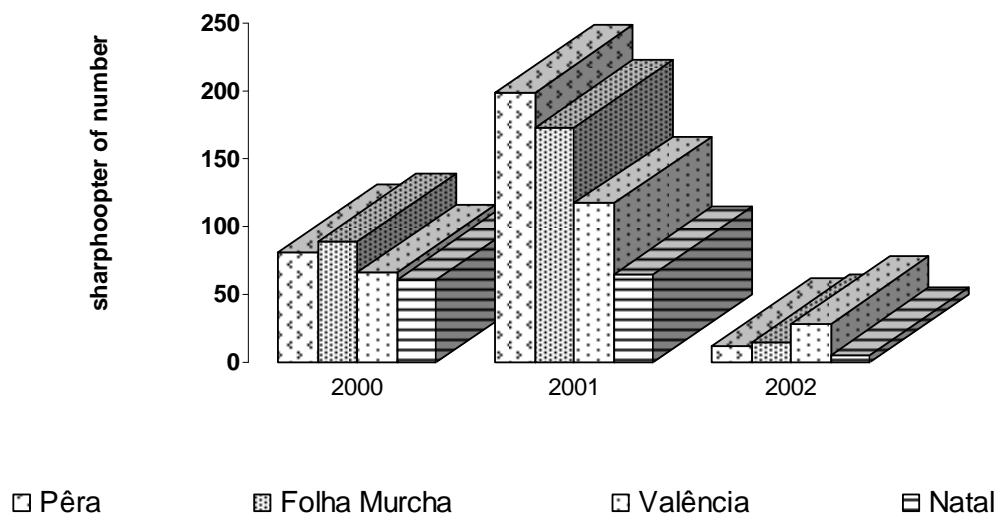

Figure 1 - Number of vectors species identified in the sweet orange varieties of Pêra, Valência, Folha Murcha and Natal in the period 2000 to 2002.

However a lesser incidence of insects was observed in 2002 with a significant reduction in the number of captured sharpshooters in all the evaluated sweet oranges. This variation in the population fluctuation probably occurred due the change in the cultural practices of the orchard, such as the spraying of insecticides for the control of sharpshooter and also, due the constant mowing of the ground vegetation in the rows of the plots where the collections of these insects had been carried out. Another important fact was the climate, and the population fluctuation of the insect vectors was directly related to the temperature of the periods of winter and summer.
Molina (2006), Nunes et al. (2007), in previous studies in this same area concluded that in years of atypical winter, that is, with high temperatures for that period, the population of sharpshooter tended to be bigger than the expected at that time. Leite et al. (2000), observed that for cicadelids in general, variations of temperature and photoperiod influenced the population fluctuation in the development of nymphs and the coloration (pigmentation) of the adults, causing alterations not only in the physiological characteristics, but also in its morphologic characteristics.

This, the knowledge about the population of insects and it's dynamics, most prevalent species 
in the orchards and an analysis of the transmission probability, would contribute for definition of a more rational time for the control of the vectors, aiming at the reduction in the dissemination of the CVC in the orchards in Paraná State, Brazil.

\section{CONCLUSIONS}

The obtained results evidenced that the species Dilobopterus costalimai and Acrogonia citrina were the most prevalent in the evaluated citrus varieties. The Pêra variety was the one that presented the biggest amount of captured insects in the year 2001 .

\section{ACKNOWLEDGEMENTS}

We are thankful to the Pratinha family proprietors of the Laranjeira Farm, for allowing the accomplishment of this work and to the support of the Conselho Nacional de Desenvolvimento Científico e Tecnológico (CNPq).

\section{RESUMO}

A Clorose variegada dos citros (CVC) é uma importante doença que ocorre nos citros, cujo agente causal é a bactéria Xylella fastidiosa, Wells. A bactéria depende, obrigatoriamente, de insetos vetores para sua disseminação, que são as cigarrinhas sugadoras do xilema (Hemiptera: Cicadellidae, Cicadellinae). No presente estudo objetivou-se avaliar a flutuação populacional de espécies de cigarrinhas nas diferentes variedades de laranja doce [Citrus sinensis (L.) Osbeck], Natal, Pêra, Valência e Folha Murcha, em um pomar comercial localizado na região Noroeste do Paraná, no período de janeiro de 2000 a dezembro de 2002. Amostragens quinzenais foram realizadas com o uso de armadilhas adesivas amarelas, num total de 24 armadilhas em cada avaliação. Após a identificação das espécies observou-se, que as mais representativas foram Dilobopterus costalimai da tribo Cicadellini e Acrogonia citrina da tribo Proconiini, sendo que a variedade de laranja Pêra apresentou o maior número de espécies vetoras durante os anos avaliados.

\section{REFERENCES}

Beretta, M.J.G., R. Harakava, C. M. Chagas, K. S. Derrick, G. A. Barthe, T. L. Ceccadi, R. F. Lee, O. Paradela, M. Sugimori and I. Ribeiro. (1996), First report of Xylella fastidiosa in coffe. Plant Dis., 80, 821

Fidalski, J., Auler, P. A. M. Tormem, V. (2000). Relations among Valencia orange yields with soil and leaf nutrients in Northwestern Paraná, Brazil. Braz. arch. biol. technol., 43, 387-391.

Freitag, J.H. (1951), Host range of Pierce's disease virus of grapes as determined by insect transmission. Phytopathology, 41, 920-934.

Gonçalves, A. M. O.; Molina, R. O.; Nunes, W. M. C.; Zanutto, C. A. (2008), Incidência de Dilobopterus costalimai Young e Acrogonia citrina Marucci and Cavichioli, em pomares cítricos no noroeste paranaense. Acta Sci., 30, 321-325.

Habermann, G.; Alvarez, R.C.F.; Modesto, J.C.; Fortes, A.M.T.; Rodrigues, J.D.; Ono, E.O. Rooting of healthy and Cvc-Affected 'Valência Sweet Orange Stem Cuttings, Through The Use of Plant Regulators. Braz. Arch. Biol. Technol., 49, 29-35.

Leite, A. C.; Nakano, Octavio Distribuição vertical e horizontal de três espécies de cicadelideos em plantas de citros. Laranja, 21, 271-288.

Leite, R.M.V.B.C. and A. P. Jacomino. (1993) Ocorrência de clorose variegada dos citros no Estado do Paraná. Summa Phytopathol.; 19, 35.

Lopes, J.R.S. (1999), Estudos com vetores de Xylella fastidiosa e implicações no manejo da Clorose Variegada dos Citros. Laranja, 20, 329-344.

Lopes, J.R.S. (1996), Mecanismos de transmissão de Xylella fastidiosa por cigarrinhas. Laranja, 17, 79-92

Marucci, R. C.; Cavichioli, R. R.; Zucchi, R. A. (2002) Espécies de cigarrinhas (Hemiptera, Cicadellidae, Cicadellinae) em pomares de citros da região de Bebedouro, SP, com descrição de uma nova espécie de Acrogonia. Rev. Braz. Entomol., 46, 149-164.

Marucci, R.C., R. R. Cavichioli and R. A. Zucchi. (1999), Chave para as espécies de cigarrinhas (Hemiptera: Cicadellidae: Cicadellinae) vetoras da clorose variegada dos citros (CVC). An. Soc. Entomol. Brasil., 28, 439-446

Marucci, R.C. (1998) Espécies de cigarrinhas (Hemiptera: Cicadellidae: Cicadellinae) em pomares de citros da região de Bebedoro (SP). M.SC. Thesis, Escola Superior de Agricultura "Luiz de Queiroz", Universidade de São Paulo, Brazil

Molina, R. O. (2006), Estudo populacional das cigarrinhas vetoras de Xylella fastidiosa em pomares cítricos da região noroeste do Paraná. M.SC. Thesis, Universidade Estadual de Maringá, Brasil. 
Molina, R. O.; Nunes, W. M. C.; Gonçalves, A. M. O.; Corazza-Nunes, M.J.; Zanutto, C. A.; Yamamoto, A. Y.; Vargas, R. G.. (2006). Ocorrência de cigarrinhas vetoras de Xylella fasidiosa em pomares cítricos do município de Loanda, no noroeste do Paraná. Laranja, 27, 243-250.

Nunes, W. M. C.; Molina, R O; Albuquerque, F. A.; Corazza-Nunes, M. J.; Zanutto, C. A.; Machado, M. (2007), A Flutuação populacional de cigarrinhas vetoras de Xylella fastidiosa em pomares comerciais de citros no noroeste do Paraná. Neotrop. Entomol., 36, 254-260.

Paiva, P.E.B., J.L. Da Silva, S. Gravena and P.T. Yamamoto. (1996), Cigarrinhas de xilema em pomares de laranja do Estado de São Paulo. Laranja, 17, 41-54.

Paradella Filho, O., Sugimori, M.H.; Ribeiro, I. J. A.; M. A. Machado, F. F. Laranjeira, A. Garcia Jr. and M. J. G. Beretta. (1995), Primeira constatação em cafeeiro no Brasil, da Xylella fastidiosa causadora da clorose variegada dos citros. Laranja, 16, 135-136.

Purcell, A.H. (1979), Control of the blue-green sharpshooter and effects on the spread of Pierce's disease of grapevines. J. Econ. Entomol., 72, 887892.

Purcell, A.H. and Finlay, A.H. (1979), Evidence for noncirculative transmition of Pierce's disease bacterium by sharpshooter leafhoppers. Phytopathology, 69, 393-395.

Roberto, S. R., A. Coutinho, J. E. O. Lima, V. S. Miranda, and E. F. Carlos. (1996), Transmissão de
Xylella fastidiosa pelas cigarrinhas Dilobopterus costalimai, Acrogonia terminalis e Oncometopia facialis (Hemiptera: Cicadellidae) em citros. Fitopatol. Bras., 21, 517-518.

Roberto, S. R. and P. T. Yamamoto. (1998), Flutuação populacional e controle químico de cigarrinhas em citros. Laranja, 19, 269-284.

Rosseti, V. and J. D. De Negri. (1990), Clorose Variegada dos Citros: revisão. Laranja, 11, 1-14.

Santos, D., Siqueira, D. L., Picanco, M. C. (2005) Flutuação Populacional de Espécies de Cigarrinhas Transmissoras da Clorose Variegada dos Citros (CVC) em Viçosa-MG. Ver. Bras. Frut., 27, 211-214. Silveira Neto, S., O. Nakano, D. Bardin and N. A. V. (1976), Manual de ecologia dos insetos. Agronômica Ceres. Piracicaba, pp. 419.

Yamamoto, P. T., Dalla Pria, W. J., Roberto, S.R., Felipp, R. M. Freitas E. P. (2001), Flutuação populacional de cigarrinhas (Hemiptera, Cicadellidae) em pomar cítrico em formação. Neotrop.Entomol., 30, 175-177.

Yamamoto, P. T., S. R. Roberto, W. Dalla Pria Junior, M. R. Felippe and E. P. Freitas (2002), Espécies e flutuação populacional de cigarrinhas em viveiro de citros no município de Mogi-Guaçu-SP. Rev. Bras. Frut., 24, 389-394.
Received: September 05, 2007; Revised: February 18, 2008; Accepted: July 02, 2009. 